\title{
PENDIDIKAN KARAKTER BERBASIS ISLAM
}

\author{
Fitroh Hayati \\ Program Studi Pendidikan Agama Islam, Fakultas Tarbiyah dan Keguruan \\ Universitas Islam Bandung, Jln. Ranggagading No. 8 Bandung \\ Email: fitrohhayatiunisba@gmail.com \\ DOI: $10.29313 /$ tjpi.v7i1.3764 \\ Accepted: May 15th, 2018. Approved: July 16th, 2018. Published: July 16th, 2018
}

\begin{abstract}
The development of lifestyles that follow the trends of western cultures causes anxiety to wane even the disappearance of ethical and moral values. Because it can cause free sex, drug use, and even brawl among school-aged children. This phenomenon encourages the government to formulate a national policy of nation character building. Islam is a religion that has a long history of developing attitudes, character and human character to the highest degree of glory by means of moral education. Prophet Mubammad was sent as the apostle of Allah in order to improve human morality. In the whole teachings of Islam, morality occupies a special position and very important.
\end{abstract}

Keywords: Education, Character, and Islam.

\begin{abstract}
ABSTRAK
Perkembangan gaya bidup yang mengikuti trend budaya-budaya barat menyebabkan kecemasan akan memudarnya babkan hilangnya nilai-nilai etis dan moral. Karena hal tersebut dapat menyebabkan terjadinya pergaulan bebas, penggunaan obat-obatan terlarang, babkan tawuran di kalangan anak usia sekolah. Fenomena tersebut yang mendorong pemerintah untuk merumuskan kebijakan nasional pembangunan karakter bangsa. Islam adalah agama yang memiliki sejarah panjang dalam mengembangkan sikap, watak, dan karakter manusia menuju derajat tertinggi kemuliaan dengan melalui pendidikan akblak. Nabi Mubammad SAW diutus sebagai rasul Allah dalam rangka memperbaiki akblak manusia. Dalam keseluruhan ajaran Islam, akhlak menempati kedudukan yang istimewa dan sangat penting.
\end{abstract}

Kata Kunci: Pendidikan, Karakter dan Islam. 


\section{PENDAHULUAN}

Pendidikan karakter akhir-akhir ini menjadi tema yang mencuat ke permukaan dan hangat diperbincangkan. Tidak kurang dari pejabat publik, seperti presiden dan para tokoh bangsa lainnya, mengeluhkan menurunnya nilai-nilai akhlak bangsa.

Fenomena yang terjadi di masyarakat adalah perilaku yang mengikuti perkembangan gaya hidup yang sedang trend. Hal ini dapat dilihat dari gaya berbusana, gaya berbicara, gaya hidup yang mengikuti budaya-budaya luar yang sedang popular. Hal tersebut menyebabkan kekacauan dan kecemasan akan nilai-nilai etis. Perilaku-perilaku tersebut menyebabkan terjadinya pergaulan bebas, penggunaan obat-obat terlarang, mabuk-mabukan dan perjudian.

Menurut Thomas Lickona, ada 10 yang indikasi yang perlu mendapat perhatian agar berubah kearah yang lebih baik, kemunduran kesadaran masyarakat yang perlu dibangkitkan agar perkembangan moral para pemuda menjadi lebih baik, yaitu : (1). Kekerasan dan tindakan anarki, (2). Pencurian, (3). Tindakan curang, (4). Pengabaian terhadap aturan yang berlaku, (5). Tawuran antar siswa, (6). Ketidaktoleran, (7). Penggunaan bahasa yang tidak baik, (8). Kematangan seksual yang terlalu dini dan penyimpangannya, (9). Sikap perusakan diri, (10). Penurunan etos kerja (Lickona, 2013).

Jika dilihat dari 10 indikasi tersebut diatas, maka hal tersebut sudah banyak terjadi dan terlihat di lingkungan sekitar kita. Seperti tawuran antar pelajar, bahkan barubaru ini terjadi tawuran di Sekolah Dasar di Semarang Jawa Tengah. Kolusi, Korupsi dan Nepotisme masih terjadi bahkan di kalangan birokrasi. Kasu-kasus pemerkosaan bahkan penjualan anak-anak dibawah umur untu dijadikan pekerja seks.

Perilaku tersebut sudah lepas dari niali-nilai moral bangsa Indonesia dan nilainilai agama Islam.

Nabi Muhammad SAW diutus sebagai rasul Allah dalam rangka memperbaiki akhlak manusia. Dalam keseluruhan ajaran Islam, akhlak menempati kedudukan yang istimewa dan sangat penting. Dalam Alqur`an terdapat kurang lebih 1500 ayat yang menjelaskan tentang akhlak. Belum terhitung hadits-hadits Nabi SAW, baik berupa perkataan (ucapan), maupun perbuatan (perilaku) beliau yang memberikan bimbingan dan pedoman akhlak yang mulia dalam seluruh aspek kehidupan. Ajaran akhlak dalam Islam disesuaikan dengan fithrah manusia. Nilai baik dan buruk, terpuji dan tercela, berlaku kapan dan dimana saja dalam segala segi dan aspek kehidupan, tidak dibatasi oleh ruang dan waktu.

Penanaman nilai-nilai akhlak pada diri manusia dapat dilakukan melalui pendidikan. Pendidikan diorientasikan pada pembentukan manusia sempurna (insan kamil) yang dalam jiwanya tertanam karakter kemanusiaan dan ketuhanan. Insan yang demikian telah tercermin dalam diri Nabi Muhammad sebagai uswah hasanah serta rujukan ideal pendidikan Islam dengan berbagai karakter yang dimilikinya. Hal tersebut menunjukkan bahwa segala karakter yang terurai dalam perilaku, sikap serta perbuatan Nabi Muhammad merupakan representasi dari Al-Qur'an yang perlu untuk dijadikan pedoman.

\section{PEMBAHASAN}

Karakter menurut Pusat Bahasa Depniknas sebagaimana yang dikutip oleh Aan Hasanah adalah bawaan, hati, jiwa kepribadian, budi pekerti, perilaku, personalitas, sifat, tabiat, temperamen, watak. Adapun berkarakter adalah berkepribadian, berperilaku, bersifat, bertabiat dan bewatak. Karakter juga berarti agregat fitur dan ciri-ciri yang membentuk sifat individu dari beberapa orang atau hal. Watak adalah sifat lain manusia yang mempengaruhi segenap pikiran dan tingkah laku, budi pekerti, tabiat dasar. Dengan demikian karakter adalah sifat-sifat kejiwaan, akhlak atau budi pekerti yang membedakan 
seseorang dengan yang lain. Endang Sumantri dalam Aan Hasanah mengatakan bahwa karakter ialah suatu kualitas positif yang dimiliki seseorang, sehingga membuatnya menarik dan atraktif; reputasi seseorang; seorang yang unusual atau memiliki kepribadian yang eksentrik. (Hasanah, 2013)

Karakter menurut pengamatan seorang filsuf kontemporer yang bernama Michael Novak sebagaimana yang dikutip oleh Thomas Lickona, merupakan "campuran kompatibel dari seluruh kebaikan yang diidentifikasi oleh tradisi religious, cerita sastra, kaum bijaksana, dan kumpulan orang berakal sehat yang ada dalam sejarah." Sebagamana yang ditunjukkan Novak, tidak ada seorangpun yang memiliki semua kebaikan itu, dan setiap orang memiliki beberapa kelemahan. Orang-orang dengan karakter yang sering dipuji bisa jadi sangat berbeda antara satu dengan lainnya. Menurut Thomas Lickona, Karakter memiliki tiga bagian atau komponen yang saling berhubungan, yaitu pengetahuan moral (moral knowing), perasaan moral (moral feeling) dan perilaku moral (moral action). Karakter yang baik terdiri dari mengetahi hal yang baik, menginginkan hal yang baik, dan melakukan hal yang baik-baik- kebiasaan dalam cara berfikir, kebiasaan dalam hati, dan kebiasaan dalam tindakan. Ketiga hal ini diperlukan untuk mengarahkan suatu kehidupan moral; ketiganya ini membentuk kedewasaan moral. (Lickona, 2013)

Dengan demikian, karakter merupakan sifat alami sesorang dalam merespon situasi secara bermoral, yang terwujud dalam tindakan nyata melalui perilaku jujur, baik, dan bertanggungjawab, hormat terhadap orang lain dan nilai-nilai karakter mulia lainnya.

Berdasarkan ketiga komponen karakter yang disebutkan di atas, dapat dinyatakan bahwa karakter yang baik harus didukung oleh pengetahuan tentang kebaikan, keinginan untuk berbuat baik, dan kemampuan melakukan perbuatan baik. Dengan kata lain, indikator manusia yang memiliki kualitas pribadi yang baik adalah mereka yang mengetahui kebaikan, memiliki keinginan untuk berbuat baik, dan nyata berperilaku baik, yang secara koheren memancar sebagai hasil dari 5 (lima) olah, yaitu olah pikir, olah hati, olah raga, olah rasa, dan olah karsa. Dan hal ini sesuai dengan grand design yang dikembangkan oleh kemendiknas tahun 2010 dalam upaya pembentukan karakter dalam diri tiap individu. (Panduan Pendidikan Karakter di Sekolah Menengah Pertama, 2011)

Pada pembentukan nilai-nilai karakter pada anak didik. Menurut FW Foerster ada empat ciri dasar pendidikan karakter, yaitu: (1) Pendidikan karakter menekankan setiap tindakan berpedoman terhadap nilai. Anak didik menghormati norma-norma yang ada dan berpedoman pada norma tersebut; (2) Adanya koherensi atau membangun rasa percaya diri dan keberanian, dengan begitu anak didik akan menjadi pribadi yang teguh pendirian dan tidak mudah terombang-ambing dan tidak takut resiko setiap kali menghadapi situasi baru; (3) Adanya otonomi, yaitu anak didik menghayati dan mengamalkan aturan dari luar sampai menjadi nilai-nilai bagi pribadinya. Dengan begitu, anak didik mampu mengambil keputusan mandiri tanpa dipengaruhi oleh desakan dari pihak luar; dan (4) Keteguhan dan kesetiaan. Keteguhan adalah daya tahan anak didik dalam mewujudkan apa yang dipandang baik. Dan kesetiaan merupakan dasar penghormatan atas komitmen yang dipilih.

Pendidikan karakter akan melahirkan pribadi yang unggul yang tidak hanya memiliki kemampuan kognitif saja namun memiliki karakter yang mampu mewujudkan kesuksesan. (Meta, 2012)

Menurut Lickona, pendidika karakter harus melibatkan teknik dan materi yang membuat seseorang mememiliki alasan dan kepentingan untuk berbudi pekerti baik yang diawali dari pengetahuan terhadap nilai kebaikan sehingga akan terus mengembangakan sikap mencintai perbuatan baik dan akhirnya mau untuk 
melaksanakan perbuatan baik tersebut. Pendidikan karakter bisa dimulai sejak dalam kandungan atau dimulai sejak dini karena karakter orang tersebut akan lebih mudah dibentuk dan dikembangkan. (Lickona, 2013)

Dari uraian di atas dapat disimpulkan bahwa pendidikan karakter adalah upaya-upaya yang dirancang dan dilaksanakan secara sistematis untuk membantu peserta didik memahami nilainilai perilaku manusia yang berhubungan dengan Tuhan Yang Maha Esa, diri sendiri, sesama manusia, lingkungan, dan kebangsaan yang terwujud dalam pikiran, sikap, perasaan, perkataan, dan perbuatan berdasarkan norma-norma agama, hukum, tata karma, budaya dan adat istiadat.

Kriteria dan tolok ukur dari sikap yang dikategorikan berkarakter adalah perilaku baik dan buruk. Sumber karakter Islam adalah Al-Qur an yang dinilai sebagai sumber kebenaran hakiki dalam kehidupan. Oleh karena itu, manusia dianjurkan untuk meneladani dan berakhlak dengan akhlak Allah.

Menurut Damsuki, karakter Islam adalah perilaku seseorang yang didasarkan pada nilai-nilai yang sesuai dengan normanorma yang berlaku dan tidak bertentangan dengan doktrin normatif Islam. Oleh karena itu karakter menjadi varian fundamental dalam kehidupan manusia untuk mencapai derajat kebahagiaan di dunia dan akhirat. Menurutnya karakter merupakan nilai-nilai perilaku manusia yang universal dan meliputi seluruh aktivitas manusia, baik dalam rangka berhubungan dengan Tuhannya, dengan dirinya, dengan sesama manusia maupun dengan lingkungannya yang terwujud dalam pikiran, sikap, perasaan, perkataan, dan perbuatan berdasarkan norma-norma agama, hukum, tata karma, budaya dan adat istiadat.

Pada konteks tersebut di atas bisa dikatakan bahwa karakter merupakan realisasi nilai-nilai yang berbentuk perilaku, sikap, dan perbuatan. Oleh karena itu dalam terminologi Islam, karakter lebih dikenal dengan akhlak, yaitu suatu sifat yang terpatri dalam jiwa yang darinya terlahir perbuatanperbuatan yang selaras dengan Al-Qur`an dan al-Hadits dengan mudah tanpa memerlukan pemikiran dan perenngan terlebih dahulu (Damsuki, 2015)

Ratna Megawangi sebagaimana yang dikutip oleh Aan Hasanah, merinci karakter mulia dengan mengemukakan Sembilan pilar karakter mulia yang selayaknya dijadikan acuan dalam pendidikan karakter, baik di sekolah maupun di luar sekolah, yaitu: (a) Cinta kepada Allah dan kebenaran. (b) Tanggung jawab, disiplin, dan mandiri. (c) Amanah. (d) Hormat dan santun. (e) Kasih sayang, peduli, dan kerjasama. (f) Percaya diri, kreatif, dan pantang menyerah. (g) Adil dan berjiwa kepemimpinan. (h) Baik dan rendah hati. (i) Toleran dan cinta damai (Hasanah, 2013).

\section{Pendidikan Karakter menurut Islam}

Menurut Damsuki, dalam terminologi Islam, karakter lebih dikenal dengan akhlak, yaitu suatu sifat yang terpatri dalam jiwa yang darinya terlahir perbuatanperbuatan yang selaras dengan Al-Qur an dan al-Hadits dengan mudah tanpa memerlukan pemikiran dan perenungan terlebih dahulu (Damsuki, 2015)

Sejarah Islam menegaskan bahwa zaman jahiliyah adalah masa suram yang dialami oleh bangsa Arab pada masa itu. Dimana perilaku menyimpang terjadi, seperti pemerkosaan, pembunuhan terhadap bayi perempuan, perjudian, mabuk-mabukan, perjudian. Perilaku tersebut sudah berakar dan sudah menjadi tradisi yang melekat sehingga sangat sulit untuk dilepaskan.

Dengan realitas perilaku menyimpang dan budaya jahiliyah yang melekat pada bangsa Arab, Allah mengutus Muhammad sebagai nabi dan rasul Allah. Tugas utama nabi Muhammad adalah memperbaiki perilaku sesat yang dilakukan oleh bangsa Arab pada masa itu. Tujuan utama diutusnya nabi Muhammad adalah untuk menyempurnakan akhlak umatnya, sebagaimana sabdanya: 


\section{انما بعثت لأتمم مكارم الأخلاق}

"Aku banya diutus untuk menyempurnakan akblak".

Nabi Muhammad sebagai rasul Allah, menegaskan bahwa diutusnya beliau sebagai seorang rasul Allah dalam rangka memperbaiki akhlak umatnya. Sebagaimana Beliau menghiasi dirinya dengan akhlak yang mulia.

Akhlak menurut imam al-Ghazali adalah suatu sifat yang menetap pada jiwa seseorang yang mendorong untuk melakukan sesuatu perbuatan (lahir) dengan mudah tanpa membutuhkan pemikiran lagi. Oleh karena itu akhlak adalah nilai dan pemikiran yang telah menjadi sikap mental yang mengakar dalam jiwa, kemudian tampak dalam bentuk tindakan dan perilaku yang bersifat tetap, natural atau alamiah tanpa dibuat-buat serta refleks.

Alghazali memberikan kriterian akhlak sebagaimana yang dikutip oleh Aan Hasanah, yaitu bahwa akhlak harus menetap dalam jiwa dan perbuatan itu muncul dengan mudah tanpa memerlukan peelitian terlebih dahulu. Dengan kedua kritria tersebut, maka suatu amal itu memiliki korenspondensi dengan faktor-faktor yang saling berhubungan, yaitu : perbuatan baik dan keji, mampu menghadapi keduanya, mengethui tentang kedua hal itu, keadaan jiwa yang ia cenderung kepada salah satu dari kebaikan dan bisa cenderung kepada kekejian. Akhlak bukan merupakan perbuatan, bukan kekuatan, bukan makrifat (mengetahui dnengan dalam). Yang lebih sepadan dengan akhlak itu adalah "hal" keadaan atau kondisi; dimana jiwa mempunyai potensi yang bisa memunculkan dari padanya menahan atau memberi. Jadi akhlak itu adalah ibarat dari "keadaan jiwa atau bentuknya yang bathiniyah". Jadi konsep akhlak bersifat integral, menyeluruh dan seimbang. Bersifat integral karena akhlak tidak dapat dipisahkan dari konsep tauhid. Bersifat menyeluruh, karena mencakup seluruh aspek perkembangan manusia-intelektual, moral dan spiritual. Bersifat seimbang karena konsep akhlak mencakup hubungan vertical maupun horizontal serta memberikan dampak positif bagi kehidupan di dunia maupun di akhirat. (Hasanah, 2013)

Dalam Alqur'an, kata akhlak tidak ditemukan, yang ditemukan hanyalah bentuk tunggalnya yaitu khuluq. Sebagaimana yang tercantum dalam QS. AlQalam: 4, yaitu:

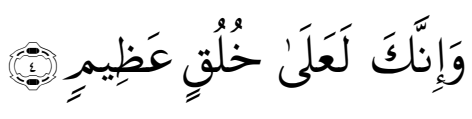

"Dan Sesunggubnya kamu benar-benar berbudi pekerti yang agung".

M. Quraish Shihab dalam tafsir alMisbah mengatakan bahwa ayat ini mengesankan Nabi Muhammad saw. berada di atas tingkat budi pekerti yang luhur, bukan sekedar berbudi pekerti luhur. Allah menegur Rasulullah jika bersikap dengan sikap yang hanya baik dan telah biasa dilakukan oleh orang-orang yang dinilai sebagai berakhlak mulia. Keluhuran budi pekerti nabi Muhammad saw yang mencapai puncaknya itu bukan saja dilukiskan oleh ayat di atas dengan innaka (sesungguhnya engkau), tetapi juga dengan tanwin (bunyi dengung) pada kata kbuluqin dan huruf lam yang digunakan untuk mengukuhkan kandungan pesan yang menghiasi kata ala disamping kata ala itu sendiri. (Shihab, 2008)

Karena keluhuran budi pekerti nabi Muhammad maka beliu dijadikan contoh oleh Allah untuk umat manusia. Sebagaimana firman Allah dalam QS. AlAhzab: 21:

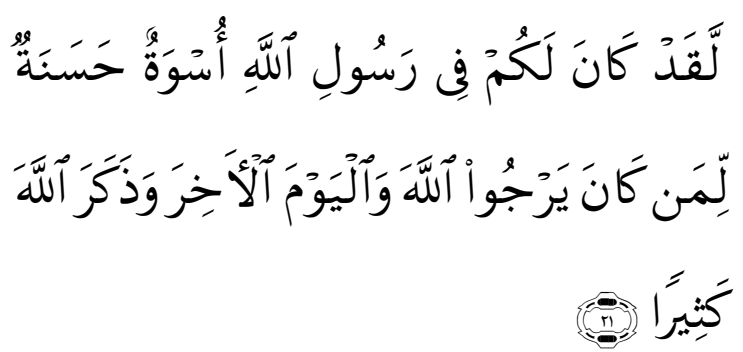

Sesunggubnya telah ada pada (diri) Rasulullah itu suri teladan yang baik bagimu (yaitu) bagi orang yang mengharap (rahmat) Allah dan (kedatangan) hari kiamat dan Dia banyak menyebut Allah.

Keteladanan tersebut dapat dilakukan oleh setiap manusia, karena beliau 
telah memiliki segala sifat terpuji yang dapat dimiliki oleh manusia.

Dengan memahami konsep dasar pendidikan karakter, maka dapat dipastikan bahwa al-Qur an telah menjelaskan konsep pendidikan karakter dengan menggunakan term akhlak sebagaimana yang terbaca dalam ayat dan hadits di atas.

Urgensi dan eksistensi akhlak dalam ajaran Islam dapat dipahami dari hadits Nabi saw. Ketika didatangi oleh Jibril dan diajukan tiga pertanyaan tentang pengertian Iman, Islam dan Ihsan, yang artinya:

Dari Abu Hurairah ia berkata: suatu hari Nabi keluar di tengah kerumunan manusia tiba-tiba didatangi oleh jibril dan bertanya kepada Rasulullah, apa itu iman? Nabi menjawab; iman itu adalah percaya kepada Allah, para Malikat, kitab-kitab, pertemuan dengan-Nya (di akbirat), pra rasul, dan kebangkitan. Jibril kembali bertanya, apa itu islam? Nabi menjawab: Islam itu adalah menyembah kepada Allah dan tidak menyekutukan-Nya, melaksanakan sholat, menunaikan rakat yang wajib, dan berpuasa pada bulan ramadhan. Jibril bertanya lagi, apa itu ihsan? Nabi menjawab: ibsan itu adalah engkau menyembah Allah seakan-akan engkau melihatNya, jika engaku tidak meliban-Nya, maka yakinlah bahwa Dia melihatmu (HR Bukhari)

Hadits di atas dapat dipahami bahwa ajaran Islam mengandung tiga dimensi pokok, yaitu keimana, ibadah dan akhlak. Iman biasa diartikan dengan pembenaran. Sementara ulama mendefinikan iman dengan pembenaran hati terhadap seluruh yang disampaikan oleh Nabi Muhammad saw. Dengan demikian, iman tidak terbatas pada pengakuan akan keesaan Tuhan, tetapi mencakup pembenaran tentang banyak hal. Bahkan tidak sedikit pakar yang menekankan tiga aspek pembenaran, yaitu hati, lidah dan perbuatan. Seorang yang beriman dituntut untuk mengucapkan pembenaran tersebut, tidak hanya disimpan dalam hati, melainkan harus dapat dibuktikan dengan perbuatan. Dengan demikian, aspek keimanan dalam ajaran Islam juga mengandung pesan moral.
Ibadah juga ddemikian, sehingga dapat dipahami bahwa Islam sangat mementingkan pentingnya pendidikan karakter.

Perhatian Alqur'an terhadap pendidikan karakter dapat dibuktikan dengan banyaknya ayat dalam Alqur'an yang berkaitan dengan akhlak, meskipun kata-kata akhlak itu sendiri jumlah sedikit, tetapi substansi dari ayat-ayat tersebut berkaitan dengan akhlak. Hal itu disebabkan karena seluruh aspek ajaran Islam yang disebut di dalam Alqur an mengandung nilai-nilai pendidikan karakter.

Akhlak adalah ajaran agama yang tidak dapat disamakan dengan etika, jika etika dibatasi pada sopan santun antara sesama manusia, serta hanya berkaitan dengan tingkah laku lahiriyah. Menurut M. Quraish Shihab, sasaran akhlak adalah akhlak kepada Allah dan akhlak kepada makhluk Allah. (Shihab, 2013)

\section{Akhlak kepada Allah}

Titik tolak akhlak kepada Allah adalah pengakuan dan kesadaran bahwa tiada Tuhan melainkan Allah. Dia memiliki sifatsifat terpuji; demikian agung sifat itu, yang jangankan manusia, malaikatpun tidak akan mampu menjangkau hakikat-Nya.

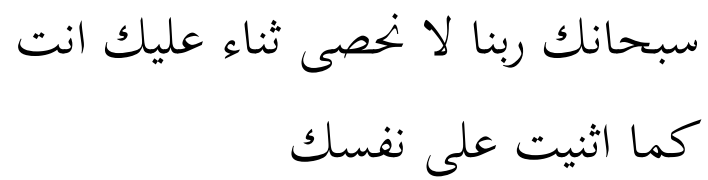

Maha suci engkau wahai Allah, kami tidak mampu memuij-Mu; pujian atas $M u$ adalah yang Engkau pujikan kepada diri-Mu

Kalimat tersebut adalah ucapan para malaikat. Itulah sebabnya mengapa AlQur`an mengajarkan kepada manusia untuk memuji-Nya. Sebagaimana dalam QS. AnNaml: 93:

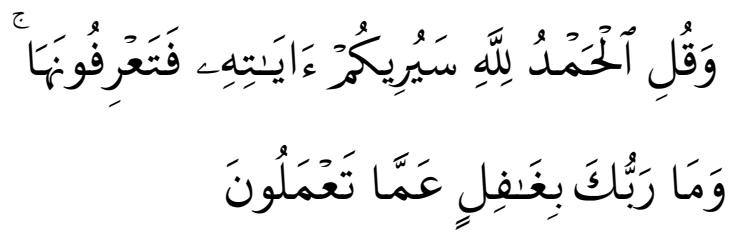


Dan Katakanlah: "Segala puji bagi Allah, Dia akan memperlibatkan kepadamu tanda-tanda kebesaran-Nya, Maka kamu akan mengetahuinya. dan Tuhanmu tiada lalai dari apa yang kamu kerjakan".

Hal dia atas menunjukkan bahwa makhluk tidak dapat mengetahui dengan baik dan benar betapa kesempurnaan dan keterpujian Allah SWT. Itu sebabnya mereka sebelum memujiNya, bertasbih terlebih dahulu dalam arti menyucikan-Nya. Jangan sampai pujian yang mereka ucapkan tidak sesuai dengan kebesaran-Nya. Al-Qur'an memerintahkan manusia untuk berserah diri kepada-Nya, karena segala yang bersumber dari-Nya adalah baik, benar, indah dan sempurna.

\section{Akhlak terhadap Sesama Manusia}

Banyak sekali rincian yang dikemukakan Alquran berkaitan denagn perlakuan terhadap sesame manusia. Petunjuk mengenai hal ini bukan hanya dalam bentuk larangan melakukan hal-hal negative seperti membunuh, menyakiti badan, atau mengambil harta tanpa alasan yang benar, melainkan juga sampai kepada menyakiti hati dengan jalan menceritakan aib seseorang di belakangnya, tidak peduli aib itu benar atau salah, walaupun sambil memberikan materi kepada yang disakiti hatinya itu. Sebagaimana firman Allah dalam QS Al-Baqarah: 263:

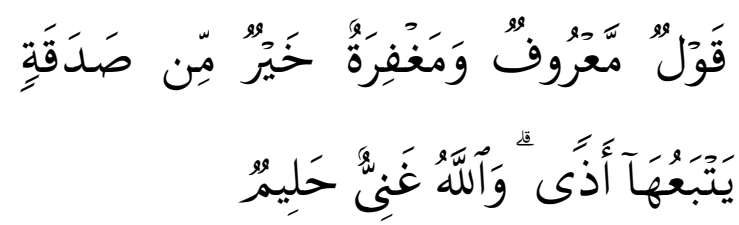

Perkataan yang baik dan pemberian maaf lebih baik dari sedekah yang diiringi dengan sesuatu yang menyakitkan (perasaan si penerima). Allab Maha Kaya lagi Maha Penyantun.

\section{Akhlak terhadap Lingkungan}

Yang dimaksud lingkunagn disini adalah segala sesuatu yang berada di sekitar manusia, baik binatang, tumbuh-tumbuhan maupun benda-benda tak bernyawa. Pada dasarnya, akhlak yang diajarkan Al-Qur'an terhadap lingkungan bersumber dari fungsi manusia sebagai khalifah. Kekhalifahan menuntut adanya interaksi antar manusia dengan sesamanya dan manusia terhadap alam. Kekhalifahan mengandung arti pengayoman, pemeliharaan, serta pembimbingan, agar setiap makhluk mencapai tujuan penciptaannya.

Dalam pandangan akhlak Islam, seseorang tidak dibenarkan mengambil buah yang sebelum matang, atau memetik bunga sebelum mekar, karena hal ini berarti tidak memberi kesempatan kepada makhluk untuk mencapai tujuan penciptaannya. Hal ini berarti manusia dituntut untuk mampu menghormati proses-proses yang sedang berjalan, dan terhadap semua proses yang sedang berjalan, dan terhadap semua proses yang sedang terjadi. Yang demikian mengantarkan manusia bertanggung jawab, sehingga tidak melakukan perusakan.

Nabi Muhammad saw, bersabda:

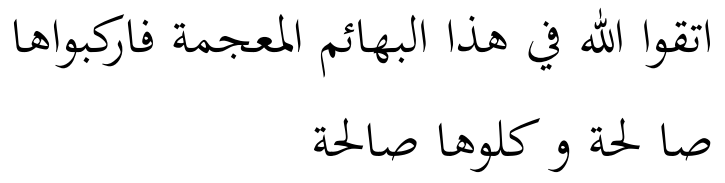

Bertakwalah kepada Allah dalam perlakuanmu terhadap binatang, kendarailah, dan beri makanlah dengan baik (Shihab, 2013).

Dari uraian di atas dapatlah disimpulkan bahwa konsep pendidikan karakter dalam Islam dapat ditemukan dalam tiga sasaran akhlak yang harus diaktualiasikan dalam diri manusia, yaitu akhlak kepada Allah, akhlak kepada sesama manusia, dan akhlak kepada makhluk lain .

Al-Qur an memberikan perhatian yang besar terhadap pendidikan karakter. Fazlur Rahman mengatakan bahwa dasar ajaran Alquran adalah moral yang memancarkan titik beratnya pada monoteisme dan keadilan social. Hukum moral tidak dapat diubah. Ia merupakan perintah Tuhan; manusia tidak dapat membuat hukum moral; bahkan ia sendiri harus tunduk kepadanya. Kentundukan itu disebut Islam dan perwujudan Islam dalam 
kehidupan disebut ibadah atau pengabdian kepada Allah. (Rahman.terj, 1997)

Pendidikan karakter menurut Islam dalam hal ini menurut Alqur’an ditujukan untuk: (1) mengeluarkan dan membebaskan manusia dari kehidupan yang gelap (tersesat) kepada kehidupan yang terang (lurus) sebagaimana dalam QS. Al-Ahzab : 43, (2) Menunjukkan manusia dari kehidupan yang keliru kepada kehidupan yang benar sebagaimana dalam QS. Al-Jumu ah: 2, (3) Mengubah manusia yang biadab (jahiliyah) menjadi manusia yang beradab. Sebagaimana dalam QS. Al-Baqarah: 67, dan (4) Mendamaikan manusia yang bermusuhan menjadi bersaudara, dan menyelamatkan manusia yang berada di tepi jurang kehancuran, menjadi manusia yang selamat dunia dan akhirat. Sebagaimana dalam QS. Ali-Imran: 103 (Nata, 2012).

\section{Tujuan dan Fungsi Pendidikan Karakter}

Menurut Meta, pendidikan karakter pada intinya bertujun membentuk bangsa yang tangguh, kompetitif, berakhlak mulia, bermoral, bertoleran, bergotong royong, berjiwa berpatriotik, berkembang dinamis, berorientasi ilmu pengetahuan dan teknologi yang semuanya dijiwai oleh iman dan takwa kepada Tuha yang Maha Esa berdasarkan Pancasila. Pendidikan karakter berfungsi untuk: (a) Mengembangkan potensi dasar agar berhati baik, berpikiran baik, dan berperilaku baik; (b) Memperkuat dan membangun perilaku bangsa yang multikultur; dan (c) Meningkatkan peradaban bangsa yang kompetitif dalam pergaulan dunia.

Pendidikan karakter dilakukan melalui berbagai media yang mencakup keluarga, satuan pendidikan, masyarakat sipil, masyarakat politik, pemerintah, dunia usaha, dan media massa (Meta, 2012)

Menurut Aan Hasanah, tujuan pendidikan karakter berbasis Islam adalah terbentuknya anak didik yang memiliki karakter keimanan, kejujuran, tanggung jawab, kepedulian, keberanian serta menjadi warga Negara yang baik. Tujuan pendidikan karakter bukan hanya untuk menjawab masalah-masalah bangsa yang bersifat kondisional, seperti kemorosotan moral yang terjadi di Indonesia dewasa ini, melainkan pula harus diletakkan pada perspektif filosofis dan paedagogis yang pada gilirannya akan menjadi bagian penting dari kajian ilmu kependidikan. (Hasanah, 2013)

Menurut Damsuki, pendidikan karakter menurut Islam bertujuan untuk meningkatkan mutu penyelenggaraan dan hasil (outcomes) pendidikan Islam yang mengarah pada pencapaian pembentukan karakter dan akhlak mulia (akhlak alkarimah) peserta didik secara holistic, integralistik dan seimbang secara orientasi duniawi dan ukhrawi (Damsuki, 2015)

Sedangkan menurut Ali Abdul Halim Mahmud bahwa tujuan pendidikan akhlak adalah membimbing umat manusia di atas prinsip kebenaran dan jalan lurus, jalan Allah yang dapat mewujudkan kebahagiaandunia-akhirat mereka. Akhlak yang baik adalah tujuan pokok pendidikan akhlak dan akhlak tidak disebut baik kecuali jika sesuia dengan ajaran Alqur`an. (Mahmud, 2003)

Dari uraian di atas tentang tujuan dari pendidikan karakter, maka dapat disimpulkan bahwa tujuan dari pendidikan karakter adalah meningkatkan kesadaran dan pengetahuan terhadap nilai-nilai kemanusiaan; nilai-nilai budaya, social dan agama; menanamkan nilai-nilai kejujuran, loyalitas dan integritas; meningkatkan kemampuan mengendalikan emosi, dan bersikap terbuka; melatih kepekaan dan kepedulian terhadap lingkungan; meningkatkan rasa tanggungjawab dan kedisiplinan generasi muda; melatih kemampuan membedakan yang baik dan yang buruk.

\section{KESIMPULAN}

Pendidikan karakter
hakekatnya merupakan usaha
membentuk watuk
watan budi pekerti


seseorang sehingga mempunyai kepribadian yang luhur. Sumber utama dari pendidikan karakter Islam adalah Alqur`an. Sedangkan contoh yang dijadikan panutan dalam pendidikan karakter Islam adalah Nabi Muhammad yang memiliki akhlak mulia. Diharapkan manusia dapat berakhlak mulia sebagaimana yang dicontohkan oleh nabi Muhammad saw.

Sasaran pendidikan karakter Islam atau akhlak adalah Akhlak kepada Allah dan akhlak kepada makhluk-Nya, yaitu akhlak kepada sesama manusia dan akhlak kepada sesama makhluk hidup.

Tujuan dari pendidikan karakter Islam adalah meningkatkan kesadaran dan pengetahuan terhadap nilai-nilai kemanusiaan; nilai-nilai budaya, sosial dan agama; menanamkan nilai-nilai kejujuran, loyalitas dan integritas; meningkatkan kemampuan mengendalikan emosi, dan bersikap terbuka; melatih kepekaan dan kepedulian terhadap lingkungan; meningkatkan rasa tanggungjawab dan kedisiplinan generasi muda; melatih kemampuan membedakan yang baik dan yang buruk.

\section{DAFTAR PUSTAKA}

Damsuki. (2015). Percikan Pemikiran Pendidikan Islam. Jakarta: Raja Grafindo Persada.

Hasanah, Aan. (2013). Pendidikan Karakter Berperspektif Islam. Bandung: Insan Komunika.

Lajnah Pentashihan Mushaf Al-Qur`an. (2014). Tafsir Al-Qur'an Tematik. Jakarta: Kamil Pustaka.
Lickona, Thomas. (2013). Educating for Character terj. . Jakarta: Bumi Aksara.

Mahmud, Ali Abdul Halim. (2003). Tarbiyah Kbuluqiyab; Pembinaan Diri menurut Konsep Nabawi. terj. Solo: Media Insani.

Megawangi, Ratna. (2004). Pendidikan Karakter Solusi yang tepat untuk. Membangun Bangsa. Jakarta: BP Migas dan Star Energy.

Meta. (2012, April). https:/ /pndkarakter.wordpress.com/ categ ory/tujuan-dan-fungsi-pendidikan-

karakter/. Retrieved from https://pndkarakter.wordpress.com /category/tujuan-dan-fungsipendidikan-karakter/.

Nata, Abudin. (2012). Kapita Selekta Pendidikan Islam; Isu-Isu Kontmporer tentang Pendidikan Islam. Jakarta: Rajawali Pers.

Pertama, K. P. (2011). Panduan Pendidikan Karakter di Sekolah Menengah Pertama. Jakarta: Diknas.

Rahman. Fazlur. (1997). Islam. terj. Bandung: Pustaka.

Shihab, M. Quraish. (2008). Tafsir al-Misbab; Pesan, Kesan dan Keserasian Al-Qur'an. Jakarta: Lentera Hati. (2013). Wawasan AlQuran; Tafsir Tematik atas Pelbagai Persoalan Umat. Bandung: Mizan. 